\section{Discussion}

The patients in this series were typical of the patients admitted to our hospital for the treatment of painful crisis. The finding of a mild respiratory alkalosis during the steady state is interesting, but is not specific for sickle-cell anaemia, because this has been reported in patients with anaemia from other causes (Manfredi, 1965). The normal acid-base status during the acute painful episodes emphasizes the fact that metabolic acidosis is not responsible for the initiation of spontaneous painful crisis. The data presented are in direct contrast to the results of Barreras and Diggs (1964), who noted severe metabolic acidosis in their patients. We cannot at this time offer an adequate explanation for this difference, but there may be geographical variations in the severity of the painful crises. Finally, these results support our belief that alkalis are of little use in either the prevention or the treatment of the painful crisis of sickle-cell anaemia, at least in our population.
We are indebted to Professor J. C. Waterlow, Director of the Tropical Metabolism Research Unit, for his support, and to Dr. Graham Serjeant, who is in charge of the Sickle Cell Clinic of the University Hospital of the West Indies, for referring many of the patients under his care.

One of us (H. H.P.K.) was supported by a grant from the Wellcome Trust.

\section{REFERENCES}

Barreras, L., and Diggs, L. W. (1964). American fournal of the Medical Sciences, 247, 710 .

Diggs, L. W. (1965). American fournal of Clinical Pathology, 44, 1.

Greenberg, M. S., Kass, E. H., and Castle, W. B. (1957). Fournal of Clinical Investigation, 36, 833.

Greenberg, M. S., and Kass, E. H. (1958). Archives of Intermal Medicine, 101,355 .

Hugh-Jones, K., Lehmann, H., and McAlister, J. M. (1964). British Medical fournal, $2,226$.

Manfredi, F. (1965). American Review of Respiratory Disease, 92, 617. Nwokolo, C. (1960). West African Medical fournal, 9, 194

\title{
Operative Treatment of Typhoid Perforation of the Bowel
}

\author{
E. Q. ARCHAMPONG,* B.SC., F.R.C.S., F.R.C.S.ED.
}

British Medical fournal, 1969, 3, 273-276

Summary : One hundred and twenty-one proved cases of typhoid perforation were seen in a three-year period; the incidence of perforation, $17.9 \%$, is the highest recorded. All patients were treated by laparotomy with closure and drainage. The mortality was $29.8 \%$, but $76 \%$ when operation was performed after the fifth day of perforation.

\section{Introduction}

Enteric fever remains a pressing clinical problem in the developing countries of the tropics and ileal perforations from this cause claim high mortalities of about 20 to $40 \%$ (Palmer, 1951 ; Huckstep, 1960). In Ghana the incidence of perforation is unusually high ; Badoe (1966), in a review of 37 cases, recorded an incidence of $15.4 \%$ with a mortality of $30.4 \%$.

Opinion is still divided on the place of surgery in the management of typhoid perforations. Huckstep (1962) advocated conservative measures, and $\mathrm{Li}$ (1963), among others, favoured the operative approach. This paper reports a series of 121 proved cases of typhoid perforation treated operatively. The results were sufficiently encouraging to suggest that a reappraisal of the general attitude to management of this complication of enteric fever is needed.

\section{Methods and Materials}

For this study cases of typhoid perforation admitted to Korle Bu Hospital during 1966-8 were examined. This involved the pooling of the work of 12 surgeons of varying degrees of seniority and experience, so that the differences due to changing technical skill were eliminated. The study was essentially prospective, and information was obtained by means of a detailed form. To avoid doubt that perforation had actually occurred only cases treated operatively were included in the series: these numbered 121. Eleven patients treated conservatively and nine who died within a few hours of admission before treatment was instituted were excluded.

\section{Results}

There were 789 cases of enteric fever admitted to Korle Bu Hospital over the three-year period; 141 (17.9\%) of these had perforations-a high incidence. There was considerable variation in yearly incidence of the disease, but the proportion with perforations remained unchanged (see Table II) ; 110 (90\%) had perforated on admission, while 11 perforated under medical care.

Age Incidence.-The youngest in the series was a boy of 2 and the oldest a man of 51. Table I shows the breakdown of age incidence. The highest incidence was in the second and third decades ; indeed, all but 15 patients were aged 6 to 34 years. This was perhaps fortunate, since the mortality outside these age limits rises sharply.

\begin{tabular}{|c|c|c|c|c|c|c|}
\hline \multirow{2}{*}{ Age } & \multirow{2}{*}{ Male } & \multirow{2}{*}{ Female } & \multicolumn{2}{|c|}{ Tota } & \multicolumn{2}{|c|}{ Died } \\
\hline & & & No. & $\%$ & No. & $\%$ \\
\hline $\begin{array}{r}\text { Under } 5 \\
5-9 \\
10-19 \\
20-29 \\
30-39 \\
40+\end{array}$ & $\begin{array}{r}6 \\
18 \\
25 \\
20 \\
18 \\
4 \\
91\end{array}$ & $\begin{array}{r}3 \\
10 \\
16 \\
- \\
1 \\
30\end{array}$ & $\begin{array}{r}9 \\
28 \\
41 \\
20 \\
18 \\
5 \\
121\end{array}$ & $\begin{array}{r}7 \cdot 4 \\
23 \cdot 2 \\
33.9 \\
16.5 \\
14.9 \\
4 \cdot 1 \\
100.0\end{array}$ & $\begin{array}{r}5 \\
10 \\
10 \\
4 \\
4 \\
3 \\
36\end{array}$ & $\begin{array}{l}55 \cdot 6 \\
35 \cdot 7 \\
24 \cdot 4 \\
20.0 \\
22 \cdot 2 \\
60.0 \\
29.8\end{array}$ \\
\hline
\end{tabular}

Sex Incidence.-Of the 121 patients 91 were males and 30 were females, a sex ratio of $3: 1$. Over the age of 20 there was only one woman. This male preponderance is noticeable in several reports (Rowland, $1961 ; \mathrm{Li}, 1963$ ). Examination of the total figures for typhoid shows a female incidence of $35 \%$, so that the apparent difference in perforations is only a reflection of the incidence of typhoid in the sexes as seen in hospital. It may be that fewer females with typhoid fever report to hospital, and then only when seriously ill. This would explain the higher female mortality noted by all workers. In this series female mortality was $33.3 \%$ compared with male figures of $22 \%$.

* Lecturer, Department of Surgery, Ghana Medical School, Accra, 
Periodicity.-Typhoid perforations show a definite seasonal incidence, with clustering around two peaks in May-August and October-November. The same seasonal behaviour is shown by patients with typhoid who are not treated surgically (see Fig.). Correlation with weather conditions indicates that these periods coincide with the two rainy seasons, when varying degrees of flooding may lead to contamination of water and food. Peak incidence is reached not at the heights of rains but soon after this, owing to the time lag in development of the disease. Weather conditions are reflected in the yearly incidence: thus 1968 was the wettest year for 70 years, and it also had the highest recorded typhoid perforation rate (Table II).

TABLE II.-Yearly Incidence of Typhoid Perforations in Relation to Annual Rainfall

\begin{tabular}{|c|c|c|c|c|c|}
\hline Year & $\begin{array}{c}\text { Total } \\
\text { Perforations }\end{array}$ & $\begin{array}{c}\text { Typhoid } \\
\text { Cases }\end{array}$ & $\begin{array}{c}\text { Incidence } \\
\text { No. }\end{array}$ & $\begin{array}{l}\text { Yearly } \\
\text { Rainfall } \\
\text { (in.) }\end{array}$ & $\underset{\%}{\text { Mortality }}$ \\
\hline $\begin{array}{l}1966 \\
1967 \\
1968\end{array}$ & $\begin{array}{l}37 \\
34 \\
70\end{array}$ & $\begin{array}{l}220 \\
192 \\
377\end{array}$ & $\begin{array}{l}16 \cdot 8 \\
17 \cdot 7 \\
18 \cdot 6\end{array}$ & $\begin{array}{l}22.62 \\
31.94 \\
65 \cdot 68\end{array}$ & $\begin{array}{l}37 \cdot 5 \\
27 \cdot 6 \\
25 \cdot 0\end{array}$ \\
\hline Total & 141 & 789 & $17 \cdot 9 \%$ & & \\
\hline
\end{tabular}

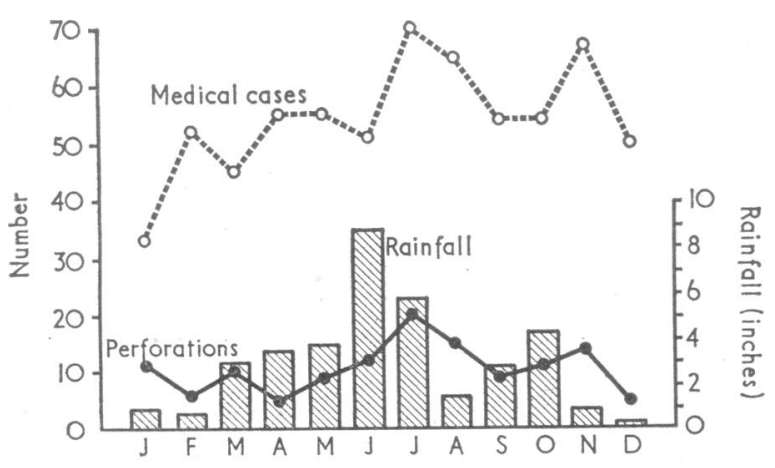

Seasonal incidence of typhoid fever cases and perforations.

\section{Diagnosis}

In diagnosis the emphasis was on the clinical symptoms and signs, with a minimum of confirmatory investigations. The clinical features were elicited by means of a detailed form, and since the interview was checked by at least one other person who saw all the patients a high degree of consistency was ensured.

The diagnosis of enteric fever may be difficult enough, but to establish that perforation has occurred may be even more perplexing. While it may be assumed that patients with headaches, joint pains, high fever, and associated abdominal pain, tenderness, and guarding may have typhoid perforation, the classical signs of perforation are often absent (Table III). Owing to extreme toxaemia signs are in abeyance, and the first indication of perforation in an abdomen which is already doughy and tender may be the discovery of free fluid.

Vomiting or its intensification was often noticed at the time of perforation. Bowel sounds may also be absent, but this sign

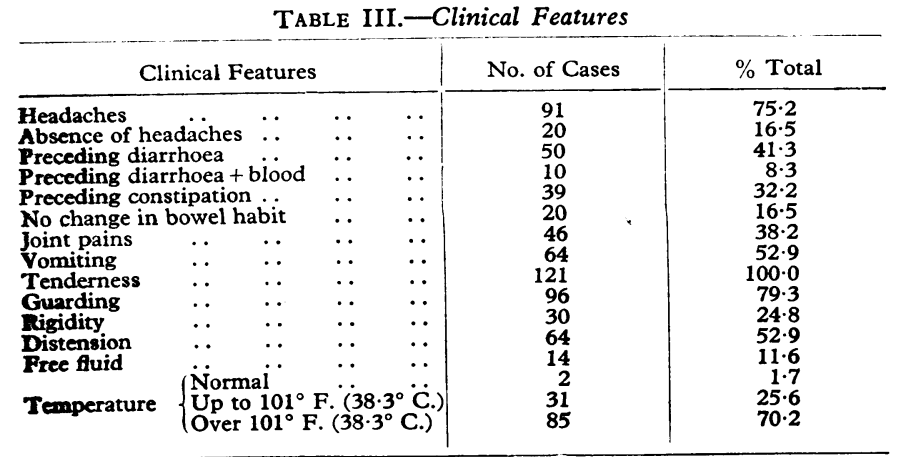

is not always of much value owing to the frequency of some degree of ileus in the toxic typhoid patient. Liver dullness is often diminished or absent, and this is a useful combination in diagnosis.

$X$-ray films are of confirmatory value, as indicated by Bohrer (1966), who found radiological evidence of perforation in 10 out of 12 cases. In the present series $x$-ray films were taken, not routinely but in situations of doubt; in 17 out of 22 cases conclusive evidence of perforation was found.

\section{Treatment}

All patients had parenteral chloramphenicol in doses between $500 \mathrm{mg}$. six-hourly and $1 \mathrm{~g}$. four-hourly for adults and 250 to $500 \mathrm{mg}$. six-hourly for children under 12 . In retrospect larger doses could be given in adults with advantage. Over half the cases had an additional antibiotic; either erythromycin or tetracycline, to deal with other bowel organisms. In most patients energetic preoperative resuscitation was essential, and cases presenting with peripheral circulatory failure required measures for combating endotoxic shock (hydrocortisone, chlorpromazine, and plasma substitutes). Provided it was adequately corrected presentation with circulatory collapse did not affect prognosis significantly.

At operation peritonitis was generalized in all but three patients and the quantities of pus were estimated at about a pint $(570 \mathrm{ml}$.) in 34 cases and 2 pints $(1,140 \mathrm{ml}$.) and above in 71 cases.

The findings were as follows:

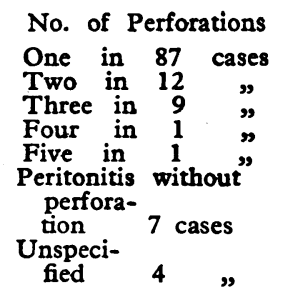
Distance from Ileocaecal Valve 0-15 cm. in 38 cases $16-30 \mathrm{~cm}$. in 43 , $31-45 \mathrm{~cm}$. in 17 , Unspecified in 20 ",

Closure was effected in two layers; the appendix was removed when easily accessible. It was not apparent that this additional procedure added to the morbidity or mortality.

\section{Complications}

Respiratory complications, mainly in the form of bronchopneumonia, were diagnosed in 15 survivors and at necropsy in five further cases. It was difficult to establish how far anaesthetic agents could be blamed, but their effect was probably not important, as most of the cases occurred in the late postoperative phase in patients showing general deterioration.

Severe anaemia is a notable feature of the immediate postoperative period; haemoglobin levels of 2-3 g. $/ 100 \mathrm{ml}$. are not uncommon. The anaemia is usually of the normocytic hypochromic type, largely from toxic marrow depression superimposed on iron deficiency of chronic malnutrition, and responds to iron. Trial of the total iron-dextran technique (Basu, 1963 ; Ashby, 1967, 1969) on these patients is currently being conducted.

Wound sepsis was recorded in 64 of the 121 cases. This is an inevitable result of a combination of gross peritonitis and - lowered resistance, and contributed to the prolonged average stay in hospital. Pelvic abscesses were uncommon, two cases being recorded. Recovery was rapid after drainage. Incisional hernia, often the result of sepsis, was recorded in seven patients ; these were repaired subsequently without incident. Burst abdomen is to be expected in a condition associated with distension and prolonged sepsis; it occurred in three cases, and one patient died. Faecal fistula was recorded in four patients- 
two died of gross toxaemia, the other two survived with spontaneous closure of the fistula. Toxic confusion occurred in varying degree from mild disorientation to wild and aggressive behaviour in 19 patients. They responded well to chlorpromazine 25 mg. t.d.s. With prompt and energetic treatment the complication, contrary to popular belief, did not carry a worse prognosis. Renal failure was the cause of death in two patients ; in both cases the failure was extrarenal, though toxic effects on the kidney may have contributed. One case of orchitis was noted on the 10 th postoperative day.

\section{Mortality and Prognosis}

There were 36 deaths, a mortality of $29 \cdot 8 \%$. The commonest cause of death was toxaemia leading to peripheral circulatory failure. Toxic myocardial degeneration, a common necropsy finding, was a contributory factor. Ten patients died within 24 hours of operation, but in only three of these were there significant respiratory lesions implicating the anaesthetic. The remaining deaths were evenly distributed over the succeeding two weeks.

Prognosis depended on several factors, prime among which was the perforation-admission interval, the mortality rising steeply after the fifth day of perforation (Table IV). The symptom complex of diarrhoea with blood is associated with increased mortality. In seven out of 10 such cases the patient eventually died. The bleeding probably implies more extensive bowel necrosis.

TABLE IV.-Mortality in Relation to Perforation-Operation Interval

\begin{tabular}{|c|c|c|c|c|c|}
\hline \multicolumn{2}{|c|}{$\begin{array}{l}\text { Perforation-Operation } \\
\text { Interval }\end{array}$} & \multirow{2}{*}{$\begin{array}{c}\text { Survived } \\
\begin{array}{r}39 \\
31 \\
6 \\
9\end{array}\end{array}$} & \multirow{2}{*}{$\begin{array}{c}\text { Died } \\
6 \\
11 \\
19 \\
-\end{array}$} & \multirow{2}{*}{$\begin{array}{c}\text { Total } \\
45 \\
42 \\
25 \\
9\end{array}$} & \multirow{2}{*}{$\begin{array}{c}\text { Mortality } \\
13 \cdot 3 \\
26 \cdot 2 \% \\
76 \cdot 0 \% \\
\end{array}$} \\
\hline $\begin{array}{l}\text { Within } 24 \text { hours } \\
\text { 2-5th day } \\
\text { After 5th day } \\
\text { Unspecified }\end{array}$ & $\begin{array}{l}. . \\
\because \\
\cdots\end{array}$ & & & & \\
\hline Total . & . & 85 & 36 & 121 & 29.8 \\
\hline
\end{tabular}

Impaired renal function was contributory to the mortality; when the blood urea exceeded $100 \mathrm{mg}$. $/ 100 \mathrm{ml}$. survival was unusual, probably owing to intrinsic renal lesions superimposed on an extrarenal uraemia. This was also the experience of Dickson and Cole (1964) in Ibadan. The nutritional state of the patient is an important factor, for while typhoid perforations were evenly distributed the mortality was largely confined to the slum areas of the district.

\section{Discussion}

The high incidence of perforation $(17.9 \%)$ is a peculiarity of enteric fever in Ghana. The nearest recorded figure to this was $3.5 \%$ from Cairo ( $\mathrm{El}$ Ramli, 1950) in a report of seven perforations in 200 cases of typhoid fever. From South India Dunkerley (1946) reported 22 perforations in 1,088 typhoid cases, and from Abadan, in Iran, Rowland (1961) reported 8 in 530 cases.

One explanation for the phenomenal incidence of perforation may be that many cases of typhoid fever never come to hospital, and support for this comes from the large numbers already perforated on admission. While this may be true of Ghana as a whole it probably does not apply on an appreciable scale to the capital, where the need for admission to hospital of patients with protracted fever is appreciated.

A second hypothesis is that the local Salmonella strain is virulent, producing fulminating intestinal lesions (Badoe, 1966). Evidence for this derives from the fact that, according to the history, most perforations occurred earlier than recognized, in the first week, when the disease is still in the septicaemic stage, so that blood cultures are often positive and the Widal reaction negative (Table V). Comparative virulence studies would elucidate the issue, but one observation against this line of investigation is that in South India, where the incidence of perforation is low and mortality correspondingly low, this complication still occurs predominantly in the first week (Dunkerley, 1946).

The other possible explanation lies in host resistance. While it is likely that lowered immunological response may render the ileum a weaker target for salmonellae of average virulence the possibility of an allergy caused by tissue antibodies from previous contact cannot as yet be excluded. The Widal test or the T.A.B. status of the patient, which refer only to plasma factors do not affect this. Biopsies from early perforations with positive blood culture do not show the typical typhoid lesions but rather aggregations of lymphocytes and plasma cells reminiscent of an allergic response. Clearly more investigations are needed in this direction.

\begin{tabular}{|c|c|c|c|c|c|}
\hline $\begin{array}{l}\text { Time of } \\
\text { Perforation }\end{array}$ & & $\begin{array}{l}\text { No. of } \\
\text { Cases }\end{array}$ & $\begin{array}{l}\text { Blood Culture } \\
\text { Positive on } \\
\text { Admission }\end{array}$ & $\begin{array}{c}\text { Positive } \\
\text { Widal on } \\
\text { Admission }\end{array}$ & $\begin{array}{l}\text { Positive Stool } \\
\text { Culture on } \\
\text { Admission }\end{array}$ \\
\hline $\begin{array}{l}\text { Day } 1-7 \\
\text { Day } 8-18 \\
\text { Day } 15-28 \\
\text { Over 28th day } \\
\text { Unspecified }\end{array}$ & $\begin{array}{l}\ldots \\
\cdots \\
\cdots \\
\cdots\end{array}$ & $\begin{array}{r}89 \\
8 \\
1 \\
1 \\
2\end{array}$ & $\begin{array}{r}48 \\
1 \\
= \\
-\end{array}$ & $\begin{array}{l}2 \\
7 \\
1 \\
1 \\
5\end{array}$ & $\begin{array}{l}\frac{1}{3} \\
-\end{array}$ \\
\hline
\end{tabular}

There is a wide divergence of opinion regarding the management of typhoid perforation. Huckstep (1962), impressed by friability of the ileum and poor general state of the typhoid patient with perforation, advocated a predominantly conservative approach. While not disputing this view it is not the impression of the surgeons whose work is reviewed that closure of the ileum is unduly burdensome. With careful manipulation it has been accomplished and necropsies of non-survivors have shown no cases of subsequent perforation.

For practical reasons the management was operative in all the cases. The diagnostic difficulty of excluding acute abdominal conditions such as appendicitis, a disease on the increase locally (Badoe, 1967), was a frequent problem. Of 10 patients found to have been misdiagnosed as cases of enteric perforation at operation four had perforated appendicitis, two had unspecified perforations associated with ascaris worms, two had intestinal obstruction from adhesions, and two had atypical duodenal ulcer perforations. This emphasizes the fact that patients in tropical practice often present with multiple pathology, which makes diagnosis difficult, so that where serious doubt exists operative measures are more expedient.

The operative findings were in agreement with the experience of $\mathrm{Li}(1963)$-that there is no suggestion of localization of the inflammation with the omentum some distance away from the lesion. Some of the perforations were as much as $2.5 \mathrm{~cm}$. across and in $19 \%$ of cases they were multiple, with five perforations in one case. Spontaneous closure would seem unlikely in such cases, and operative intervention is the only way of preventing the persistent soiling of the peritoneum, which inevitably enhances the toxaemia.

In this series $90 \%$ of the cases perforated before admission and would therefore not have had any antibiotic treatment to sterilize the bowel. But even for patients who have had chloramphenicol under medical care it is doubtful whether this antibiotic sterilizes the ileal contents. These facts significantly strengthen the case for operative intervention.

The operative mortality of $29 \cdot 8$ compares favourably with results obtained by conservative measures ( $30 \%$ by Huckstep, 1962), but no objective conclusions on this point can be arrived at except by a controlled clinical trial. Nevertheless, the latter would introduce difficult diagnostic problems, for there is always the question whether the cases treated successfully by conservative means were indeed perforated. Experience with this series would indicate that some selection based on the perforation-admission interval would improve results. Thus of 
the 36 deaths 19 (76\% mortality for the group) occurred after the fifth day of perforation though there were survivors from cases presumed to have been perforated for two weeks. It would be instructive to determine whether these cases would do better on the conservative regimen.

My thanks are due to Mr. E. A. Badoe, of the department of surgery, for encouragement during the study and for reading the manuscript and making valuable comments ; to $\mathrm{Mr}$. S. W. Briandt, medical illustration department, for producing the Fig. ; and to the surgeons of Korle Bu Hospital whose cases are reviewed. For the figures on monthly and annual rainfall I am indebted to Mr. E. S. A. Quaye, of the Meteorological Services, Accra.
REFERENCES

Ashby, E. C. (1967). Lancet, 2, 807

Ashby, E. C. (1969). Ghana Medical fournal, 8, 25.

Badoe, E. A. (1966). Ghana Medical fournal, 5, 83.

Badoe, E. A. (1967). Ghana Medical fournal, 6, 69.

Basu, S. K. (1963). Lancet, 1, 1430

Bohrer, S. P. (1966). British fournal of Radiology, 39, 37.

Bickson, J. A. S., and Cole, G. J. (1964). British fournal of Surgery, 51, 893 .

Dunkerley, G. E. (1946). British Medical fournal, 2, 454.

E1 Ramli, A. H. (1950). Lancet, 1, 618.

Huckstep, R. L. (1960). Annals of the Royal College of Surgeons of England, 26, 207.

Huckstep, R. L. (1962). Typhoid Fever and Other Salmonella Infections. Edinburgh, Livingstone.

Li, F. W. P. (1963). British fournal of Surgery, 50, 976.

Palmer, E. D. (1951). Clinical Gastroenterology. New York, Hoeber.

Rowland, H. A. K. (1961). fournal of Tropical Medicine and Hygiene, 64, 143.

\section{Preliminary Communications}

\section{Insulin and Corticoid Response to Intravenous Fructose in Relation to Glucose Tolerance}

British Medical fournal, 1969, 3, 276-277

\begin{abstract}
Cummary : In 12 subjects with normal glucose tolerance $\checkmark$ fructose infusion was associated with a rise in plasma insulin and plasma corticoid levels. Similar but lesser changes were seen in seven maturity onset diabetics in whom there was also a considerable rise in blood glucose. It is suggested that a catabolite of fructose is responsible for these changes.
\end{abstract}

\section{INTRODUCTION}

While investigating the disturbance of carbohydrate metabolism associated with myocardial infarction it was found that fructose infusion caused significant rises in plasma insulin and blood glucose. It has been stated that fructose does not stimulate insulin secretion in man (Samols and Dormandy, 1963 ; Swan et al., 1966) or animals (Grodsky et al., 1963 ; Coore and Randle, 1964 ; Goetz et al., 1967). This communication describes the changes in plasma insulin, plasma corticoid, and blood glucose in subjects with normal and abnormal glucose tolerance after fructose infusion. The effects of fructose on plasma levels of these hormones have not been previously described in such subjects.

\section{Materials AND Methods}

Twelve convalescent men (aged 43-70 years) with normal glucose tolerance who were in a general medical ward comprised the control group. The diabetic group comprised two male and five female maturity onset diabetics (aged 28-68 years) treated by diet alone. All patients readily agreed to participate in this study.

Infusions were made via a catheter introduced into the superior vena cava; blood samples were also obtained by this route. After the catheter had been in situ for at least half an hour the control subjects were given either $50 \mathrm{ml}$. of $62.5 \%$ fructose or an equivalent quantity of $50 \%$ glucose over five minutes. The diabetics received only fructose. Ninety minutes after the first sugar had been infused the other sugar was given in the same way. Half the controls received the fructose infusion first and the glucose second, and in this respect the order was purely random.

Blood was withdrawn for insulin and corticoid assay before and 30 minutes after each infusion. Blood sugar was estimated on blood taken before and 60 minutes after each fructose infusion. Plasma fructose was measured at five-minute intervals after time had been allowed for mixing until one hour after the fructose infusion.

Blood sugar was estimated on a Technicon AutoAnalyzer (Technicon AutoAnalyzer Methodology, 1963). Plasma fructose was estimated by the method of Kulka (1956). Plasma corticoid was measured by Mattingly's (1962) method, and plasma insulin by the method of Hales and Randle (1963). Values for blood glucose were calculated by subtracting $90 \%$ of the appropriate fructose level from the concomitant blood sugar level.

\section{RESULTS}

The results are summarized in the Table. In the control group plasma insulin levels showed a mean rise of $25 \cdot 3 \mu \mathrm{U} / \mathrm{ml}$. 30 minutes after fructose. The diabetic group showed a smaller mean rise of $14.0 \mu \mathrm{U} / \mathrm{ml}$. The difference between the two groups was not significant. Mean plasma insulin levels rose about twice as much after glucose as after fructose in the control subjects $(57.4 \mu \mathrm{U} / \mathrm{ml}$.), this difference being highly

\begin{tabular}{|c|c|c|c|c|}
\hline & & $\begin{array}{l}\text { Plasma insulin } \\
\text { Mean } \pm \text { S.E.M. } \\
(\mu \mathrm{U} / \mathrm{mi} .)\end{array}$ & $\begin{array}{c}\text { Plasma corticoid } \\
\text { Mean } \pm \text { S.E.M. } \\
(\mu \mathrm{g} . / 100 \text { ml. })\end{array}$ & $\begin{array}{c}\text { Blood glucose } \\
\text { Mean } \pm \text { S.E.M. } \\
\text { (mg./100 ml.) }\end{array}$ \\
\hline $\begin{array}{l}\text { Control subjects: } \\
\text { Before fructose } \\
\text { Change after fructose } \\
\text { Before glucose } \\
\text { Change after glucose }\end{array}$ & $\begin{array}{l}\cdots \\
\therefore \\
\cdots\end{array}$ & $\begin{array}{r}36 \cdot 0 \pm 2 \cdot 0 \\
+25 \cdot 3 * \pm 5 \cdot 7 \\
35 \cdot 8 \pm 2 \cdot 5 \\
+57 \cdot 4^{*} \pm 8 \cdot 9\end{array}$ & $\begin{array}{r}21 \cdot 1 \pm 2.5 \\
+3 \cdot 8+ \pm 1.9 \\
20 \cdot 0 \pm 2.4 \\
-3 \cdot 1+ \pm 1.0\end{array}$ & $\begin{array}{c}74 \cdot 8 \pm 5 \cdot 8 \\
-1 \cdot 8 \mp \pm 4 \cdot 0 \\
-\end{array}$ \\
\hline $\begin{array}{l}\text { Diabetic subjects: } \\
\text { Before fructose } \\
\text { Change after fructose }\end{array}$ & $\because$. & $\begin{array}{r}39.9 \pm 6.8 \\
+14.0 \pm 5.9\end{array}$ & $\begin{array}{r}29.9 \pm 2.4 \\
+0.9 \pm 2.7\end{array}$ & $\begin{array}{c}168 \cdot 9 \pm 25 \cdot 2 \\
+50 \cdot 6 \ddagger \pm 5 \cdot 1\end{array}$ \\
\hline
\end{tabular}

Significant differences: $* P<0.005 .+P<0.0025 . \neq P<0.0001$. 